\title{
PENDAMPINGAN PRAKTIK BUDAYA NEMBANG MACAPATAN SEBAGAI WAHANA SARASEHAN PEMBUDAYAAN NILAI-NILAI PANCASILA
}

\author{
Suparlan Al Hakim ${ }^{* 1}$, Didik Sukriono ${ }^{1}$, Sri Untari ${ }^{1}$, Yusuf Suharto ${ }^{2}$ \\ suparlan.al.fis@um.ac.id. \\ ${ }^{1} J u r u s a n$ Hukum dan Kewarganegaraan, Fakultas IImu Sosial, Universitas Negeri Malang \\ 2Jurusan Geografi, Fakultas Ilmu Sosial, Universitas Negeri Malang \\ Diterima 25 April 2020, Diterbitkan 30 April 2020
}

\begin{abstract}
Abstrak
Kegiatan pengabdian kepada masyarakat ini dilakukan sebagai upaya untuk mengoptimalkan keberadaan produk kearifan lokal sebagai wahana atau media sarasehan pembudayaan nilai-nilai Pancasila. Lokasi penelitian berada di Desa Jugo Kecamatan Kesamben, Blitar dengan sasaran utama para budayawan dan masyarakat sekitar. Metode yang digunakan adalah pendampingan dengan fokus utama praktik budaya nembang macapatan yang di dalamnya terdapat sesi tes kompetensi dan juga praktik nilai-nilai Pancasila melalui dialog bagi peserta. Hasil pengabdian menunjukkan bahwa: 1) Hasil tes pengetahuan dan kompetensi pada peserta menunjukkan bahwa 87\% memahami konsep dan urgensi nilai-nilai Pancasila sehingga dapat dikatakan masayarakat sasaran memiliki modal untuk menjalankan kegiatan bernuansa pembudayaan nilai-nilai Pancasila; 2) Hasil analisis penguasaan penerapan teori atau praktik menunjukkan bahwa peserta mampu mempraktikkan kegiatan macapatan dengan baik mulai dari menjalankan peran sebagai pengarah, dhalang tembang, pamaca tembang, pamedhar tembang, pamireng tembang hingga melakukan dialog multikultural sebagai cara menyelesaikan konflik. Maka dari itu, kegiatan praktik macapatan ini sangat berpotensi menjadi wahana mediasi pembudayaan nilai-nilai Pancasila sekaligus penyelesaian konflik ke depannya atau bahkan dapat menjadi modal pengembangan wisata daerah berbasis nilai-nilai kearifan lokal.
\end{abstract}

Kata Kunci: Praktik Budaya; Macapatan; Sarasehan: Nilai; Pancasila

\section{PENDAHULUAN}

Dinamika kehidupan berbangsa dan bernegara selalu berjalan seiring dengan perkembangan zaman. Sejarah dunia mencatat bahwa pada awal abad ke-20 beberapa bangsa dan negara harus mengorbankan terjadinya perubahan nilai-nilai kebangsaan yang mereka miliki melalui jalan revolusi yang penuh dengan pertumpahan darah terlebih dahulu untuk "membeli" sebuah kemajuan. Sedangkan beberapa bangsa dan negara yang lain memilih untuk tetap mempertahankan nilai-nilai kebangsaan yang dimilikinya walaupun ternyata tidak lebih mudah daripada yang dihadapi oleh mereka yang memilih jalur revolusi. Salah satu negara yang berada pada kondisi kedua tersebut adalah Indonesia. Selama 74 tahun bangsa Indonesia berusaha mempertahankan nilai-nilai kebangsaannya yaitu Pancasila sebagai ideologi dan pandangan hidup untuk menghadapi segala tantangan perubahan zaman.

Dalam perjalanan yang ada, seakan sebuah ramalan yang kemudian menjadi kenyataan adalah ketika pernyataan dari salah satu pendiri bangsa yaitu Bung Karno yang berbunyi "Perjuanganku lebih mudah karena melawan penjajah. Tapi perjuangan kalian akan lebih berat, karena melawan saudara sendiri" terjadi secara nyata dalam kehidupan bangsa Indonesia. Praksis Pancasila sebagai moral bangsa, kepribadian bangsa dan pandangan hidup bangsa Indonesia masih banyak memunculkan problema yang perlu ditangani secara serius oleh seluruh bangsa Indonesia. Ancaman yang paling membahayakan bagi kehidupan bangsa Indonesia dewasa ini adalah merosotnya kesadaran terhadap wawasan kebangsaan berdasarkan Pancasila. Munculnya berbagai konflik horisontal bernuansa SARA (suku, agama, ras/etnis dan antar golongan), pemikiran disintegrasi bangsa, bahkan muncul gagasan mengganti rumusan Pancasila sebagai 'simbol identitas bangsa' dengan rumusan Piagam Jakarta, tentu bisa membahayakan persatuan dan kesatuan bangsa bahkan bertentangan dengan semboyan 'Bhinneka Tunggal Ika', yang menggambarkan realitas sosial dan budaya bangsa Indonesia yang bersifat pluralismultikultural. Terlebih lagi, perkembangan ideologi radikal trans-nasional dewasa ini yang mampu 
merambah kehidupan global, patut diwaspadai oleh bangsa Indonesia dengan menggunakan parameter jati diri, identitas, kepribadian nasional Pancasila.

Secara intern, problematika paling menyolok yang dialami bangsa Indonesia, bahwa banyak di kalangan bangsa ini masih dihadapkan pada beberapa persoalan, sekitar: (1) bangsa Indonesia masih banyak yang baru tahu terhadap Pancasila, namun belum mampu membangun praktik kehidupan yang ber-Pancasila (bangsa Indonesia baru mampu knowing Pancasila, dan belum doing Pancasila); (2) banyak kalangan yang mengatakan bahwa keterpurukan bangsa ini, disebabkan karena Pancasila. Krisis multidemensional yang menyebabkan bangsa Indonesia terpuruk dalam segala kehidupan yang kesemuanya ditujukan pada keterpurukan Pancasila; (3) ada yang mengatakan bahwa Pancasila bukanlah 'asli' Indonesia, akibatnya orang cenderung meragukan Pancasila apakah mampu digunakan dalam memecahkan persoalan kehidupan bermasyarakat, berbangsa dan bernegara Indonesia. Problematika ini juga banyak dikaji dalam penelitian lintas negara yang dilakukan Sultoni (2016) dengan hasil akhir diperlukan komitmen negara-negara akan pembudayaan nilai-nilai kebangsaan bagi generasi.

Di sisi lain, sejak pemerintah mencanangkan pendidikan karakter dalam kurikulum persekolahan sebagai upaya pembudayaan nilai-nilai Pancasila, banyak kajian dan tulisan yang mengapresiasi kebijakan tersebut. Sekalipun demikian, dalam konteks Indonesia, Pembudayaan Pancasila dan Pendidikan Karakter Indonesia tengah menghadapi persoalan besar yang memanggil seluruh komponen bangsa bertanggungjawab untuk memecahkan secara cerdas dan kontekstual. Kendatipun Gerakan Nasional Pendidikan Karakter yang secara intensif telah dimulai tahun 2010 (Kemendikbud, 2017), namun sentuhan ini belum dirasakan oleh seluruh satuan pendidikan di Indonesia. Praksis Pancasila sebagai moral bangsa, kepribadian bangsa dan pandangan hidup bangsa Indonesia masih banyak memunculkan problema yang perlu ditangani secara serius oleh seluruh bangsa Indonesia.

Selain itu, keprihatinan nasional yang melekat pada bangsa Indonesia dewasa ini adalah lemahnya ekspresi dan komitmen terhadap karakternya (Mawarti, dkk., 2018). Kinerja bangsa lebih banyak menekankan pada dimensi kehidupan yang cenderung kuantitatif dan mekanik, sementara dimensi kehidupan yang berbobot kualitatif, justru sering diabaikan (Al-Hakim, 2011). Banyak orang hanya mampu berpikir rasional yang berbasis pada ilmu-ilmu eksak, sementara kemampuan berpikir 'intuitif' (merasa, beretika, berakhlaq dan berkarakter) justru nampak lemah. Realitanya, bangsa Indonesia masih mengalami semacam split personality (Jalaluddin, 2012). Sejumlah peristiwa yang mengarah pada dekadensi moral menunjukkan bahwa bangsa ini hampir kehilangan jati dirinya sebagai bangsa yang dikenal beradab dan bermartabat. Sementara tradisi pendidikan tampak belum matang untuk memilih pendidikan karakter sebagai kinerja budaya dan religius dalam khidupan dalam masyarakat dan negara.

Di tengah kondisi tersebut, pendidikan holistik berbasis karakter yang menekankan pada dimensi etis-religius menjadi relevan diterapkan. Pendidikan holistik merupakan filosifi pendidikan yang berangkat dari pemikiran bahwa pada dasarnya pendidikan individu dapat menemukan identitas, makna, nilai-nilai kearifan budaya dan nilai-nilai spiritual. Pendidikan moral dapat membentuk generasi bangsa yang memiliki karakter yang mengakar pada keragaman budaya dalam masyarakat yang majemuk. Wacana pendidikan karakter baik pada lingkungan pendidikan formal, informal, maupun nonformal memang memperoleh perhatian yang cukup intens oleh pemerhati pendidikan maupun pemerintah (Soesetyo, 2010). Dalam Naskah Grand Design Karakter Nasional (2010), dijelaskan ada beberapa alasan mendasar yang melatari pentingnya pembangunan karakter bangsa, baik secara filosofis, ideologis, normatif historis maupun sosiokultural. Secara filosofis, pembangunan karakter bangsa merupakan sebuah kebutuhan asasi dalam proses berbangsa karena hanya bangsa yang memiliki karakter dan jati diri yang kuat yang akan eksis. Secara ideologis, pembangunan karakter merupakan upaya mengejawantahkan ideologi Pancasila dalam kehidupan berbangsa dan bernegara Indonesia.

Secara normatif, pembangunan karakter bangsa merupakan wujud nyata langkah mencapai tujuan negara, yaitu melindungi segenap bangsa dan seluruh tumpah darah Indoesia, memajukan kesejahteraan umum, mencerdaskan kehidupan bangsa dan ikut melakasanakan ketertiban dunua yang berdasarkan kemerdekaan, perdamaian abadi dan keadilan sosial. Sedangkan secara historis, pembangunan karakter bangsa merupakan dinamika dan perjalanan proses kebangsaan yang terjadi tanpa henti dalam kurun sejarah baik pada zaman penjajahan maupun pada zaman kemerdekaan. Sedangkan secara sosiokultural, pembangunan karakter bangsa merupakan suatu praktik pembiasaan (habituasi) dari potensi nilai-nilai sosiobudaya yang multikultural. Beberapa problema yang muncul tersebut tidak dapat dibiarkan begitu saja. Salah satu cara yang dapat ditempuh untuk mengatasinya adalah dengan 
menggunakan 'gerakan kultural' melalui kinerja pendidikan yang berbasis kehidupan yang bersandar pada moral, etika dan karakter serta religiusitas bangsa Indonesia.

Dalam kaitan ini, penguatan pendidikan karakter (PPK) yang di dalamnya juga mengandung pembudayaan nilai-nilai Pancasila kiranya menjadi tuntutan yang sangat mendesak. Bentuk realisasi dari konsep ini seyogyanya tidak hanya berbasis pendidikan formal di sekolah, melainkan juga dilaksanakan di dan luar sekolah seperti lembaga-lembaga sosial di masyarakat dengan menggunakan kearifan lokal sebagai modal utama. Agar masyarakat sebagai peserta didik dengan utama yang berskala besar pun juga mendapatkan pembinaan kan hal ini. Berkaitan dengan hal tersebut, di Desa Jugo, Kecamatan Kesamben, Kabupaten Blitar memiliki potensi seni dan kearifan lokal berupa "tradisi budaya macapatan" yang dikelola oleh kelompok budaya "Mangesthi Raos Tunggal". Kelompok ini berdiri sejak tanggal 25 Agustus 1994. Bahkan sekarang, di desa Jugo paguyuban macapatan tersebut berkembang menjadi tiga kelompok dusun, yaitu macapatan dusun Jugo, Sanggrahan dan Sanan. Alamat Kelompok Budaya Macapatan: Desa Jugo RT 01/RW 01, Kecamatan Kesamben, Kabupaten Blitar dengan yang diketuanya adalah Bapak Sukri, seorang Guru Sekolah Dasar Siraman 1, Kesambem Blitar. Kegiatan yang dilakukan sangat berpotensi untuk menjadi media pendidikan karakter kemasyarakatan atau pembudayaan nilai-nilai Pancasila karena sarat akan nilai-nilai manajemen konflik dalam dialog yang diselenggarakan.

Namun, ternyata terbentuknya kelompok paguyuban budaya macapatan di desa Jugo ini sendiri juga sempat diwarnai konflik horizontal, yang berlatarbelakang pada sentiman agama, etnis dan 'kecemburuan sosial' terhadap pesan materi yang digunakan dalam praktik budaya macapatan. Selama ini materi tembang yang digunakan hanya bernuansa pada suatu ajaran terhadap satu agama (Islam). Padahal, variasi agama peserta macapatan bervariasi terutama Islam, Kristen dan Hindu. Belum lagi, variasi etnis peserta yang terdiri dari suku Jawa dan suku Madura, tidak menutup kemungkinan akan menjadi potensi konflik dan kerawanan sosial. Keragaman agama dan etnis peserta, di satu sisi menunjukkan kekayaan kemajemukan dan demokrasi. Namun demikian, jika potensi itu tidak dikelola dengan baik, proporsional dan penuh dengan empati, bisa menimbulkan 'kerawan konflik'.

Maka dari itu, agar potensi kearifan lokal yang dimiliki masyarakat ini dapat betul-betul memberikan manfaat bagi lingkungan sekitar dan berkontribusi terhadap pembangunan bangsa, pengabdian berupa praktik budaya nembang macapatan sebagai wahana sarasehan pembudayaan nilai-nilai Pancasila diselenggarakan. Fokus utamanya adalah membangun sebuah model kehidupan sosial, melalui media budaya macapatan sebagai bagian dari konservasi budaya dan kearifan lokal daerah di Kabupaten Blitar.

\section{METODE}

Metode yang digunakan adalah pendampingan dengan fokus utama praktik budaya nembang macapatan yang di dalamnya terdapat sesi tes kompetensi dan juga praktik nilai-nilai Pancasila melalui dialog bagi peserta. Kegiatan dilakukan selama bulan September hingga Oktober tahun 2019 dengan peserta berasal dari anggota paguyuban budaya Mangesthi Raos Tunggal. Media pendukung yang digunakan adalah lembar tes tertulis tentang nilai-nilai Pancasila dan materi pendampingan. Tahapan kegiatan dapat dipahami melalui bagan alir yang tersaji pada Gambar 1.

Agar praktik macapatan sebagai wahana pembudayaan nilai-nilai Pancasila dapat berjalan dengan baik, maka anggota kelompok budaya macapatan harus memiliki prasarat pengetahuan tentang sarasehan/dialog, wawasan multikultural, pengetahuan tentang nilai Pancasila dan teknik bersarasehan/berdialog dengan baik sebagai penampilan aktor pluralis-multikultural. Identifikasi tentang prasyarat ini dilakukan pada saat tahapan sosialisasi di awal kegiatan. 


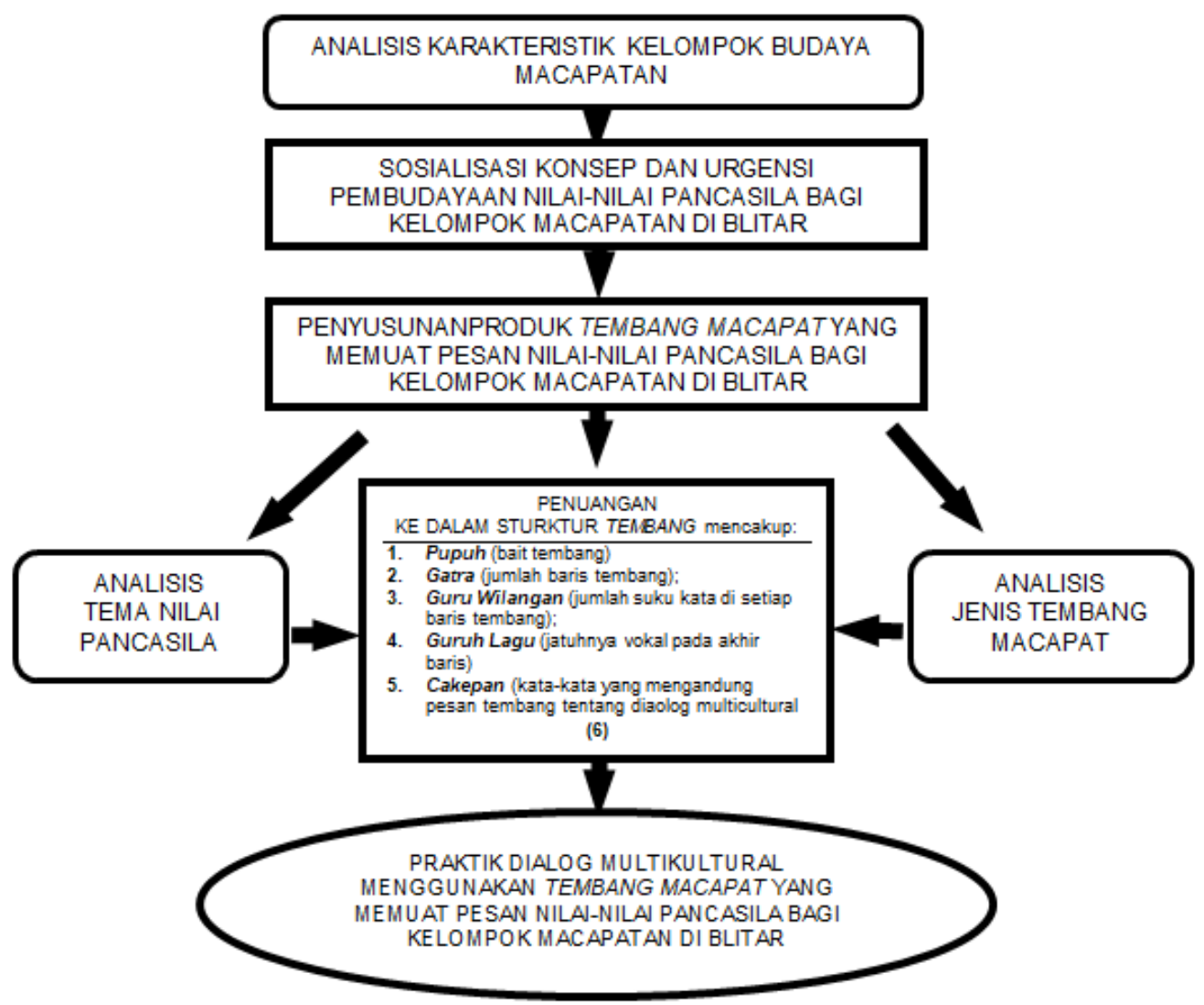

Gambar 1. Alur Pelaksanaan Kegiatan Praktik Budaya Nembang Macapatan Disusun oleh Tim Pengabdian (2019)

\section{HASIL DAN PEMBAHASAN}

Kegiatan pengabdian kepada masyarakat ini diawali pada bulan Juli tahun 2019 dengan agenda observasi dan wawancara para pengurus paguyuban Mangesthi Raos Tunggal tentang kondisi paguyuban saat ini. Hasil dari observasi memberikan sumbangsih pada informasi tentang keberadaan konflik internal dari paguyuban dan juga kecenderungan nilai-nilai yang terkandung pada syair tembang macapatan. Konflik internal yang dimaksud adalah sentiman agama, etnis dan 'kecemburuan sosial' terhadap pesan materi yang digunakan dalam praktik budaya macapatan. Selama ini materi tembang yang digunakan hanya bernuansa pada suatu ajaran terhadap satu agama (Islam). Padahal, variasi agama peserta macapatan bervariasi terutama Islam, Kristen dan Hindu. Belum lagi, variasi etnis peserta yang terdiri dari suku Jawa dan suku Madura, tidak menutup kemungkinan akan menjadi potensi konflik dan kerawanan sosial.

Setelah kegiatan observasi dan wawancara dilakukan, tim pengabdian mengadakan focus group discussion dengan perwakilan anggota paguyuban untuk membangun koordinasi yang baik tentang pelaksanaan kegiatan pengabdian kepada masyarakat. Berdasarkan hasil diskusi tersebut, tim disepakati secara bersama untuk mengatasi masalah yang ada yaitu dengan kegiatan pendampingan praktik macapatan sebagai wahana pembudayaan nilai-nilai Pancasila. Secara terperinci, solusi yang diambil antara warga dan tim pengabdian adalah memodifikasi model macapatan dari yang bersifat konvensional menjadi lebih kreatif dan mampu memfasilitasi anggota macatan untuk berdialog dalam nuansa multikultural berbasis nilai Pancasila. Realisasi dari rancangan hasil diskusi tersebut dilaksanakan pada bulan September hingga Oktober tahun 2019 dengan tahapan pelaksanaan yang selalu melibatkan masyarakat sasaran secara proaktif. Hal ini dilakukan agar pengabdian betul-betul bermanfaat bagi keberlanjutan pembangunan sosial masyarakat sendiri. Karena mengingat kecenderungan pengabdian yang selama ini banyak dilakukan oleh para akademisi adalah menjadikan masyarakat sasaran hanya sebagai objek bukan sebagai subjek. Padahal sejatinya kegiatan pengabdian hanya lah "media 
pendukung", keberhasilan perubahan sosial mutlak berada di tangan masyarakat sasaran (Mawarti, dkk, 2019).

Berkaitan dengan keberhasilan, tim pengabdian membuat indikator keberhasilan kegiatan yang dapat diketahui dari hasil evaluasi dilakukan selama proses kegiatan berlangsung sampai dengan berakhirnya kegiatan. Komponen yang dilihat untuk menunjukkan kinerja dan hasil meliputi materi teoretis dan materi yang bersifat praktis. Materi teoretis mencakup penguasaan wawasan teoretik mengenai wawasan tembang macapat bagi peserta. Sedangkan materi praktis meliputi kinerja pembuatan produk cakepan tembang macapat yang mengandung pesan nilai-nilai Pancasila.

\section{Hasil Penguasaan Teori}

Untuk penguasaan teori yang indikatornya meliputi: (1) pemahaman terhadap tembang macapat, Pancasila dan wawasan sarasehan dalam kehidupan berbangsa dan bernegara Indonesia; (2) kedudukan Pancasila sebagai dasar negara dan pandangan hidup bangsa; (3) fungsi Pancasila dalam kehidupan bangsa dan negara Indonesia; (4) syarat nembang macapat; (5) tema-tema kehidupan bangsa Indonesia sesuai sila-sila Pancasila. Pada penguasaan aspek ini, dampak kegiatan pelatihan dinyatakan "baik" jika $70 \%$ atau lebih peserta mencapai nilai 60 ke atas, dan dinyatakan "cukup baik" jika 50\% - 69\% peserta mencapai nilai kesimpulan 60 ke atas, serta dikatakan "kurang baik" jika kurang dari $50 \%$ peserta mencapai nilai kesimpulan 60 ke atas, pada skala penilaian berinterval 0 sampai dengan 100 .

Setelah dilakukan tes, hasilnya menunjukkan bahwa dari seluruh (25 orang) peserta pelatihan, sebanyak: 2 Orang mendapat nilai kesimpulan 40; 3 orang mendapat nilai kesimpulan 50; 5 orang mendapat nilai kesimpulan 60; 4 orang mendapat nilai kesimpulan 70; 4 orang mendapat nilai kesimpulan 75 ; 5 orang mendapat nilai kesimpulan 80; 1 orang mendapat nilai kesimpulan 90; dan 1 orang mendapat nilai kesimpulan 100. Jadi jumlah peserta yang mendapat nilai kesimpulan 60 ke atas adalah 15 atau $87 \%$.

Dari perspektif Pendidikan Kewarganegaraan sebagai Pendidikan Karakter, hasil dari uji kompetensi yang telah dilakukan oleh tim pengabdian kepada peserta menunjukkan bahwa civic knowledge atau pengetahuan kewarganegaraan masyarakat sasaran sudah cukup baik. Hal ini yang kemudian secara teoritis dapat mendasari berkembangnya kompetensi kewarganegaraan yang lain seperti civic skill dan kemudian menjadi civic participation (Maiello, dkk., 2003). Penjelasan dari pernyataan tersebut adalah, ketika masyarakat sasaran telah terlebih dahulu memiliki pemahaman yang baik tentang nilai-nilai Pancasila, urgensi pembudayaan nilai-nilai Pancasila, dan potensi kearifan lokal, maka proses penyusunan tembang macapat beserta praktik dialog multikulturalnya akan berjalan dengan mudah. Namun, karena hasil tes menunjukkan belum semua peserta atau masyarakat sasaran memiliki kompetensi pengetahuan kewarganegaraan yang memadai, maka dalam sesi sosialisasi para tim pengabdi yang juga merupakan akademisi di bidang Pendidikan Pancasila dan Kewarganegaraan memberikan penjelasan tentang hal-hal yang kurang dipahami. Hal ini dilakukan hingga semua peserta menyampaikan argumentasi bahwa mereka memahami materi sosialisasi dan arah kegiatan pengabdian yang diselenggarakan.

\section{Hasil Penguasaan Penerapan Teori}

Setelah proses sosialisasi yang diawali dengan tes kompetensi pengetahuan dilaksanakan, kegiatan pengabdian dilanjutkan pada tahapan penyusunan produk tembang macapat yang memuat pesan nilai-nilai Pancasila. Tahapan penyusunan ini dilakukan melalui focus group discussion dengan fokus mengangkat tema isu-isu multicultural yang sedang berkembang di masyarakat dan bagaimana pandangan Pancasila sebagai resolusi konflik atas isu tersebut. Masing-masing sila Pancasila dijabarkan dalam bentuk cakepan (syair) tembang. Hal ini dilakukan sebagai bentuk pembudayaan bahwa dalam konteks resolusi konflik, nilai-nilai Pancasila merupakan satu kesatuan sistem yang tidak dapat dipisahkan antara satu dengan lainnya. Maka dari itu, focus group discussion tidak dibentuk dengan diskusi-diskusi kecil melainkan diskusi besar bersama-sama antara tim pengabdi dan juga masyarakat sasaran. Kegiatan ini disajikan dalam Gambar 2 dan juga Gambar 3. 


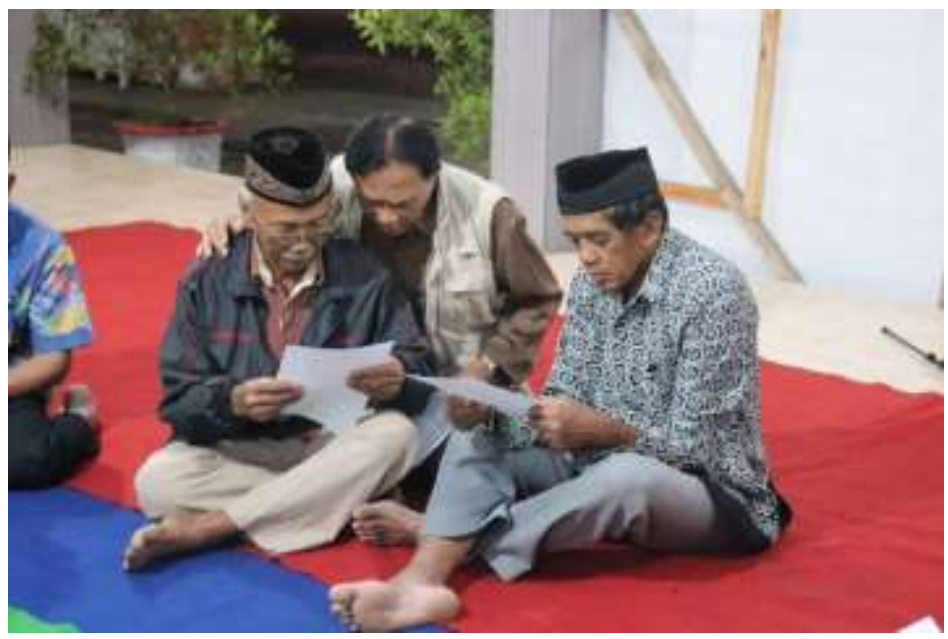

Gambar 2. Ketua Tim Pengabdian Bersama dengan Peserta Menyusun Syair Macapatan Sumber: Tim Pengabdian (2019)

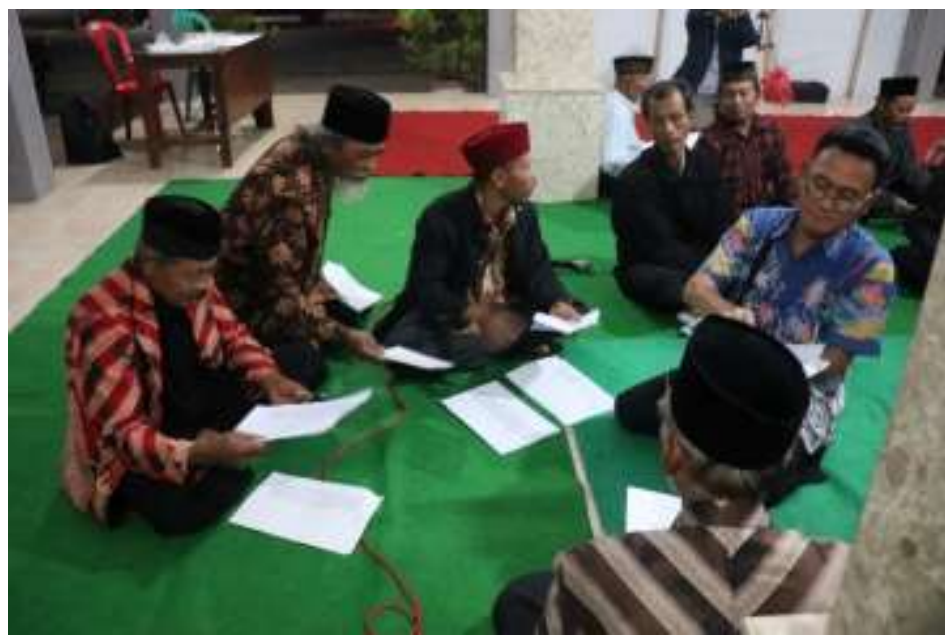

Gambar 3. Anggota Tim Pengabdian Berdiskusi Membahas Hasil Syair Macapatan Sumber: Tim Pengabdian, (2019)

Hasil dari penyusunan cakepan (syair) macapatan kemudian dibahas bersama-sama untuk dibedah kandungan nilai-nilai Pancasila nya. Selama pembahasan, jika ada peserta atau tim pengabdian yang merasa ada pilihan kata yang kurang tepat dari sisi keilmuan maupun estetika, maka forum mendiskusikan untuk mencari titik tengahnya.

Setelah tahapan penyusunan tembang macapat bersama-sama dan telah ditemukan sebuah narasi tembang yang mengandung nilai-nilai Pancasila dan sesuai dengan karakteristik paguyuban Mangesthi Raos Tunggal, kegiatan dilanjutkan dengan melakukan praktik dialog multikultural dengan media nembang macapatan. Berikut ini merupakan contoh salah satu syair tembang hasil diskusi:

\section{DHANDHANGGULA}

Dadi Warga negara puniki

Arta saben warga masyarakat

Kang sami ngugemi hake

Sarta kwajibanipun

Ora kena ameksa karsi

Tumraping wang liya

Ning mupangatipun

Ing dalem nggolongken karsa

Musyawarah murih antuk mupakat yekti

Semangat kulawarga 
Terjemahannya dalam Bahasa Indonesia, yaitu:

\author{
DHANDHANGGULA \\ Jadi warganegara itu \\ Serta setiap warga masyarat \\ Selalu memperhatikan haknya \\ Serta kewajibannya \\ Tidak boleh suka memaksa \\ Terhadap orang lain \\ Tetapi manfaatnya \\ Dalam menyatukan kehendak \\ Bermusyawarah utk mencapai mufakat \\ Dengan semangat kekeluargaan
}

Syair ini dibawakan sebagai "materi" utama diskusi yang diawali dengan pembukaan oleh pembawa acara, menyanyikan lagu Indonesia Raya, sambutan oleh tim pengabdian dan juga perwakilan paguyuban, nembang macapatan bersama-sama, dan kemudian dialog multikultural membedah isi tembang melalui mengkaitkannya dengan isu yang sednag berkembang. Semua proses ini (kecuali menyanyikan lagu Indonesia Raya) dilakukan dengan menggunakan Bahasa Jawa. Pada saat dialog, para peserta yang hadir dapat menjawab pertanyaan-pertanyaan baik menggunakan penjelasan biasa atau juga dengan melantunkan tembang macapatan yang terkait. Kegiatan yang dimaksud dapat dilihat pada Gambar 4, Gambar 5, dan Gambar 6.

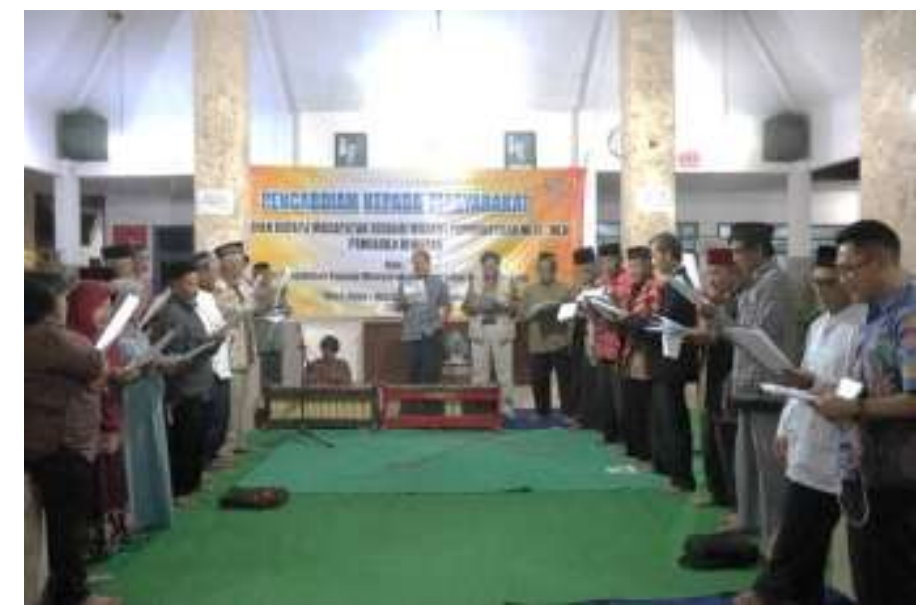

Gambar 4. Tim Pengabdian dan Peserta Melaksanakan Nembang Macapatan dengan Syair yang Mengandung Nilai-nilai Pancasila Sumber: Tim Pengabdian, (2019) 


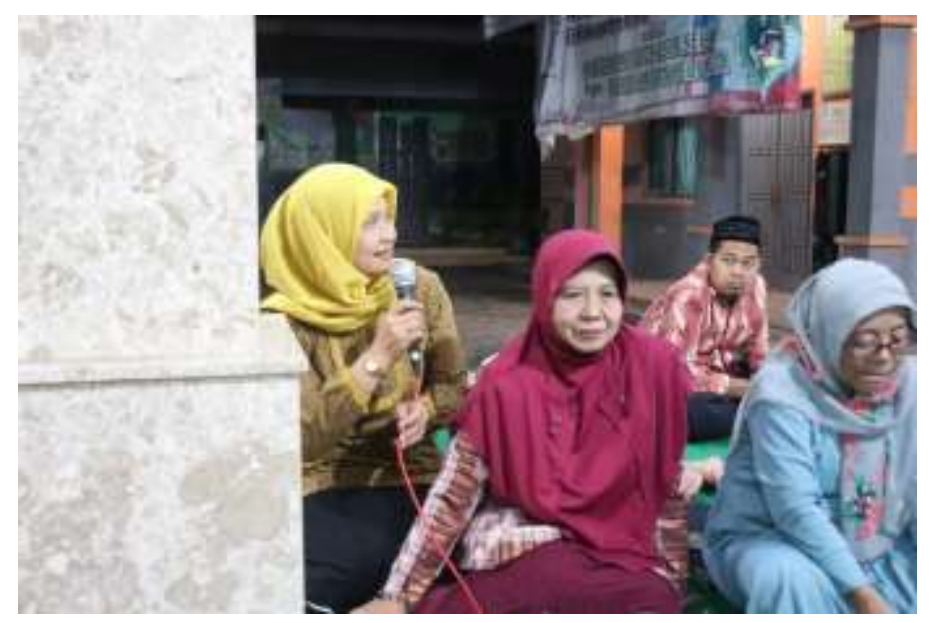

Gambar 5. Peserta Bertanya tentang Isu-isu Sosial Terkait dengan Isi Tembang Sumber : Tim Pengabdian, (2019)

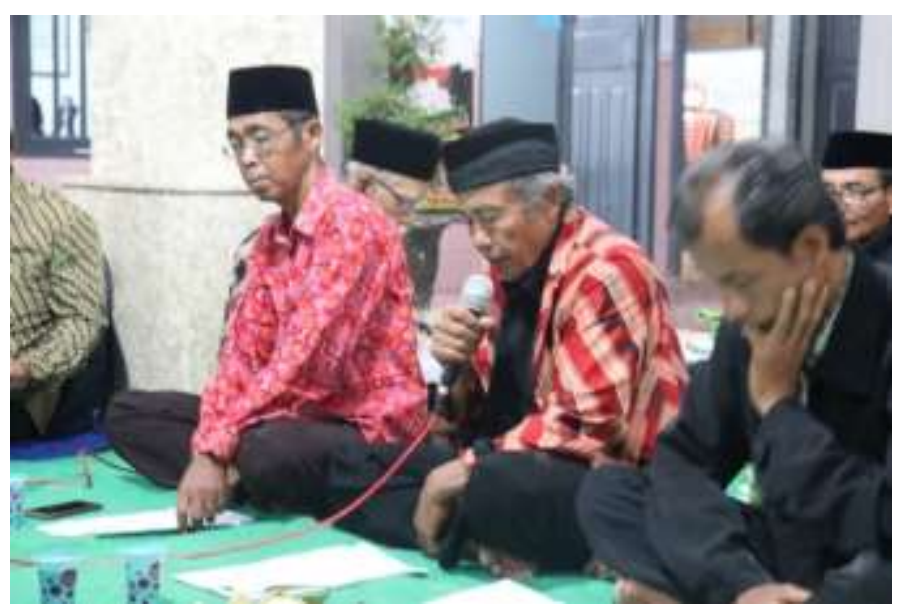

Gambar 6. Pembedah Tembang Menjawab Pertanyaan dari Peserta Sumber : Tim Pengabdian, (2019)

Dalam ketiga gambar tersebut tampak bahwa peserta sangat antusias mengikuti proses dialog multikultural yang dirancang oleh tim pengabdian. Temuan observasi ini pun menjadi salah satu bahan analisis tim pengabdian perihal keberhasilan dari pelaksanaan kegiatan.

Berkaitan dengan hal tersebut, kemudian tim pengabdian membuat indikator penguasaan penerapan teori yang meliputi: (1) Pelantunan tembang macapat yang dilihat dari aspek wiraga tembang (pedhotan), wirama (titi laras) dan wirasa (nges) atau indahnya nembang; (2) Kemampuan menerjemahkan teks tembang dalam bahasa Jawa ke dalam konteks kehidupan dengan bahasa Indonesia; (3) performansi dialog dalam mengaplikasikan pesan tembang berbasis nilai-nilai Pancasila. Kriteria keberhasilan dikatakan "baik" jika $70 \%$ peserta pelatihan mampu menampilkan praktik macapatan sesuai dengan indikator di atas; dikatakan "cukup baik" jika 50\% - 69\% peserta pelatihan mampu menampilkan praktik macapatan sesuai dengan indikator di atas; dan dikatakan "kurang baik" jika kurang dari $50 \%$ peserta pelatihan mampu mampu menampilkan praktik macapatan sesuai dengan indikator di atas.

Dalam sisi kesanggupan peserta untuk menularkan kemampuannya kepada teman sejawat kelompok macapatan. Dari 25 orang peserta pelatihan, sebanyak 10 orang menyatakan 'sangat bersedia' menularkan hasil pelatihan; dan sisanya sebanyak 15 orang peserta pelatihan menyatakan 'bersedia' menularkan hasil kegiatan pelatihan kepada teman-teman sejawatnya. Hal ini berarti bahwa $100 \%$ peserta pelatihan semuanya menyatakan "bersedia" menularkan hasil pelatihan kepada teman. Dengan demikian pada aspek ini, dampak kegiatan pelatihan dapat dikatakan berkategori baik. 


\section{KESIMPULAN}

Secara umum, kegiatan pengabdian berjalan dengan baik dan lancar. Hal ini ditandai dengan tersampaikannya semua materi dengan baik oleh tim pengabdi. Selama kegiatan ini berlangsung para peserta juga menunjukkan antusias dan keterlibatan yang tinggi, baik dalam tanya jawab, kerja kelompok dengan tim, maupun pada saat tampilan nembang macapatan. Secara khusus, capaian keberhasilan yang dimaskud adalah, 1) Hasil tes pengetahuan dan kompetensi pada peserta menunjukkan bahwa $87 \%$ memahami konsep dan urgensi nilai-nilai Pancasila sehingga dapat dikatakan masayarakat sasaran memiliki modal untuk menjalankan kegiatan bernuansa pembudayaan nilai-nilai Pancasila; 2) Hasil analisis penguasaan penerapan teori atau praktik menunjukkan bahwa peserta mampu mempraktikkan kegiatan macapatan dengan baik mulai dari menjalankan peran sebagai pengarah, dhalang tembang, pamaca tembang, pamedhar tembang, pamireng tembang hingga melakukan dialog multikultural sebagai cara menyelesaikan konflik. Maka dari itu, kegiatan praktik macapatan ini sangat berpotensi menjadi wahana mediasi pembudayaan nilai-nilai Pancasila sekaligus penyelesaian konflik ke depannya. Sebagai tindak lanjut, perlu ada penelitian tentang efektivitas upaya resolusi konflik melalui cara dialog multikultural berbasis nembang macapatan terhadap perubahan sosial atau pengabdian lanjutan yang berfokus pada peningkatan kompetensi resolusi konflik itu sendiri.

\section{UCAPAN TERIMA KASIH}

Ucapan terima kasih disampaikan kepada Universitas Negeri Malang yang telah memberikan dukungan berupa pendanaan kegiatan pengabdian PNBP Tahun 2019 dan juga seluruh pengurus maupun anggota paguyuban budaya Mangesthi Raos Tunggal yang telah bersedia bersama-sama dengan tim pengabdian mensukseskan kegiatan yang ada.

\section{DAFTAR PUSTAKA}

Al-Hakim, S. 2011. Budaya Lokal dan Hegemoni Negara dalam Kelompok Budaya Macapatan sebagai Sarana Legitimasi Politik Orde Baru. Jurnal Pendidikan Pancasila dan Kewarganegaraan: Kajian Teori dan Penerapannya. Vol. 24, No.1, HIm 50-57.

Kemdikbud. 2010. Kebijakan Nasional Pembangunan Karakter Bangsa Tahun 2010-2015. Jakarta: Kementerian Pendidikan Nasional

Jalaluddin R. 2012. Psikologi Komunikasi. Bandung. Penerbit PT Remaja Rosdakarya.

Maiello, C., dkk. 2003. Civic Knowledge, Civic Skills and Civic Engagement. European Educational Research Journal, Vol. 2, No. 3.

Mawarti, R.A. dkk. 2018. Us, The Society, and Our Pancasila: A Nowadays Service-Learning Program to Prepare the Good Citizen. Proceedings of the Annual Civic Education Conference (ACEC 2018)

Mawarti, R.A. dkk. 2019. Workshop Pengembangan Kewirausahaan Berbasis Potensi Lokal Sebagai Upaya Optimalisasi Pemberdayaan Masyarakat. Jurnal KARINOV, Vol. 2, No. 1. 